УДК 343.14:347.77(477)

DOI https://doi.org/10.51989/NUL.2021.4.34

\title{
СУБ'ЄКТИ ДОКАЗУВАННЯ У КРИМІНАЛЬНИХ ПРОВАДЖЕННЯХ ПРО ПОРУШЕННЯ ПРАВ ІНТЕЛЕКТУАЛЬНОЇ ВЛАСНОСТІ
}

\author{
Компанець Євгеній Михайлович, \\ адвокат, \\ аспірант \\ Науково-дослідного інституту інтелектуальної власності \\ Національної академії правових наук України
}

у статті досліджено теоретичні та практичні підходи до розуміння поняття «суб'єкти доказування», їх класифікацію в залежності від процесуального становища, ролі в процесі, обов'язку або права в доказуванні. Суб'єктів доказування розглянуто також через додатковий критерій - реалізацію всіх елементів процесу доказування (збирання, перевірка та оцінка доказів). Висловлено деякі критичні зауваження щодо думок та позицій науковців. За результатами аналізу Кримінального процесуального кодексу України підкреслено нечіткі, фрагментарно розкидані по Кодексу, іноді суперечливі права певних суб'єктів доказування. Висвітлено дискусійні питання реалізації суб'єктами доказування їхніх процесуальних функцій. Наведено нову позицію Великої Палати Верховного Суду щодо форми та моменту початку досудового розслідування, яку практики назвали «альтернативною» по відношенню до чинного порядку. На прикладах проілюстровано актуальні та дискусійні питання ролі суб'єктів доказування в кримінальних провадженнях про порушення прав інтелектуальної власності. Підкреслено ознаку активності потерпілого в доказуванні. Окрему увагу звернуто на форму збирання доказів потерпілим - процесуальну дію добровільної видачи документів, речей тощо. Вказано обставини, що звужують права потерпілого після пред'явлення цивільного позову. Окреслено специфіку діяльності захисника, зокрема складність спростування порушення норм матеріального права (способів використання об'єктів права інтелектуальної власності). обґрунтовано, чому експерт може бути суб'єктом доказування. Як висновок запропоновано шляхи вирішення проблемних питань.

Ключові слова: кримінальний процес, доказування, суб'єкти доказування, захист прав інтелектуальної власності.

Kompanets Yevhenii. Subjects of proving in criminal proceedings on infringing intellectual property rights

In the present article, theoretical and practical approaches to understanding of the concept of "subjects of proving" are explored as well as their classification depending on the procedural status, a role in the process, obligation and right in proving. The subjects of proving are also contemplated via the additional criterion that is realization of all elements in the process of proving (collection, verification and assessment of evidence). Some critical remarks are made about the opinions and positions of scholars. As result of the analysis of the Criminal Procedure Code of Ukraine, the vague, fragmentarily scattered, sometimes contradictory, rights of certain subjects of proving are highlighted. The debatable issues of exercising by the subjects of proving of their procedural functions are covered. The new position of the Grand Chamber of the Supreme Court on the form and starting point of the pre-trial investigation is presented, which has been called "alternative" to the current procedure by the practitioners. The examples were provided to illustrate the current and controversial issues of the role of the subjects of proving in criminal proceedings involving IP right infringements. Such characteristics as a victim's activeness in proving is highlighted. Special attention is paid to the form of evidence collection by the victim, in particular the procedural action of voluntary handing over of documents, items, etc. Circumstances that restrict the rights of the victim after filing a civil lawsuit are specified. The specifics of the defense counsel's activity are outlined, in particular the complexity of refuting the violation of the norms of substantive law (manners of use of IPR objects). The justification is provided for why an expert is a subject of proving. In conclusion, the ways to solve problematic issues are proposed.

Key words: criminal process, proving, subjects of proving, enforcement of intellectual property rights. 
Процес доказування ${ }^{1}$ присутній на всіх стадіях кримінального провадження, а тому проблеми доказування досліджувались ученими різних часових періодів: Л. Владіміровим, В. Спасовичем, I. Фойницьким, Р. Бєлкіним, П. Лупінською, М. Строговичем, Ю. Аленіним, В. Вапнярчуком, В. Галаганом, В. Гмирком, Ю. Грошевим, А. Іщенком, В. Нором, Д. Письменним, М. Погорецьким, В. Тертишником, М. Шумилом та ін. У залежності від зміни юридичної доктрини дискусійні питання доказування завжди були пов'язані із суб'єктами доказування (далі СД). Як категорія СД та їхня роль у доказуванні досліджувалася науковцями, в т.ч. на рівні дисертаційних досліджень, однак фрагментарно, щодо певних суб'єктів [1; $2 ; 3 ; 4 ; 5 ; 6]$. Аналіз юридичної літератури свідчить, що питання СД залишаються дискусійними й актуальними. Комплексне дослідження СД у кримінальних провадженнях про порушення прав інтелектуальної власності (далі - ППІВ) в науковій літературі відсутнє.

Метою статті $\epsilon$ дослідження СД у кримінальних провадженнях про ППІВ.

У кримінально-процесуальній науці, що включає як вчення про докази, так і доказове право, одними з основних категорій $\epsilon$ доказування та СД. «Серцевина кримінального процесу», «фундаментальна основа», «єдиний засіб досягнення цілей», «специфічна методологія пізнання» та інші поняття пропонують дослідники для визначення процесу доказування. Доказування здійснюють уповноважені законом учасники кримінального провадження (далі КП) з метою досягнення поставленої мети та очікуваних інтересів.

У чинному КПК, як і в КПК 1960 р., поняття СД нормативно не закріплено, а використовуються терміни: «сторони кримінального провадження» (п. 19 ч. 1 т. 3 КПК), «учасники кримінального провадження» (п. 25 ч. 1 т. 3 КПК), «учасники судового провадження» (п. 26 ч. 1 т. 3 КПК). Відсутність нормативного визначення не перешкоджає існуванню правового інституту СД, який має широке

\footnotetext{
${ }^{1}$ Доказування пропонуємо розглядати в межах традиційної концепції, яка виходить із широкого розуміння доказування - кримінальної процесуальної діяльності зі збирання, перевірки та оцінки доказів.
}

коло учасників з належними їм функціями та правами, однак дослідження розпочнемо з етимологічного аналізу слів суб'єкт-учасник, співвідношення понять «суб'єкт пізнання», «суб'єкт кримінальнопроцесуальної діяльності», «суб'єкт доказування».

Етимологічно суб'єкт - це істота, здатна до пізнання навколишнього світу; особа, якій належить активна роль у певному процесі. Учасник - той, хто бере участь у чому-небудь, входить до складу групи осіб [7, с. 879, 991]. Н. Полянський, $\epsilon$. Коваленко [8, с. 78] ототожнювали поняття «суб'єкт» і «учасник». Барабаш Т. визначає суб'єкта пізнання як «складну соціально-організовану систему, яка своїми компонентами включає різних учасників процесу (органи, окремі особи), що виступають носіями інформації про злочин або здійснюють у передбаченому законом порядку ії отримання і перетворення в достовірне знання (докази) з метою вирішення завдань КП». Оскільки суб'єкти пізнання вступають між собою в процесуальні відносини, вчена пропонує користуватися терміном «суб'єкти кримінально-процесуальної діяльності». В. Агєєв називає СД «спеціальними суб'єктами, які створені для здійснення процесу доказування, а не для взяття участі в ньому» [9, с. 111].

В. Нор, А. Ляш під СД розуміють «органи й осіб, які або зобов'язані здійснювати доказування (збирають, перевіряють, оцінюють докази) і $\epsilon$ відповідальними за нього, або мають право на активну участь у процесі доказування, реалізуючи свої охоронювані законом інтереси» [10, с. 52; 11 , с. 139]. В. Тертишник, С. Слинько виділяють СД: «органи дізнання, слідчий, прокурор і суд за участю інших суб'єктів кримінально-процесуальних відносин» [12, с. 25]. Ми не погоджуємось із запропонованим, оскільки така позиція не відповідає КПК у частині ролі потерпілого в доказуванні. О. Юхно, О. Бондаренко, В. Романюк пропонують визначати СД того учасника КП, якому належить активна роль (обов'язок або право) у процесі доказування. Активна роль як ознака СД надає можливість відмежувати його від інших учасників КП [13, с. 33]. С. Стахівський, В. Коваленко, Л. Удалова, Д. Письменний вкладають у поняття СД широкий 
зміст - «органи і посадові особи, на яких законом покладено обов'язок щодо збирання, перевірки, оцінки доказів та їхніх процесуальних джерел, обґрунтування рішень, прийнятих у процесі кримінальнопроцесуального доказування, а також інші особи, які вправі брати участь у цій діяльності» $[14$, с. $12 ; 15$, с. 129]. В. Вапнярчук, М. Погорецький визначають СД через виконувані кримінально-процесуальні функції (обвинувачення, захист, правосуддя) $[16$, с. $165 ; 17$, с. 70-74].

На основі аналізу наведених понять запропонуємо для подальшої дискусії узагальнену класифікацію суб'єктів КП у залежності від процесуального становища, об'єму прав, ролі в процесі, обов'язку або права в доказуванні:

- державні органи та посадові особи, які здійснюють КП і доказування, що є їхнім обов'язком (слідчий, керівник органу досудового розслідування, співробітник оперативного підрозділу, прокурор);

- особи, які мають інтерес удоказуванні (захищають або представляють інтереси іншої особи) та право брати участь у доказуванні (заявник, підозрюваний, обвинувачений, захисник, потерпілий, цивільний позивач, цивільний відповідач та їхні представники, законні представники);

- особи, які не мають власного інтересу в КП (свідок, спеціаліст, експерт, перекладач, понятий, слідчий суддя, суд).

Водночас підтримуємо Ю. Грошевого та С. Стахівського щодо важливого критерію для правильного визначення поняття та кола СД: «у діях яких органів та осіб містяться елементи, 3 яких складається весь процес доказування» [18, с. 45]. Саме під таким кутом ми пропонуємо дослідити реалізацію учасниками КП про ППІВ елементів процесу доказування.

Збирання доказів - комплексна діяльність СД з виявлення (пошуку), витребування, отримання та закріплення на підставі процесуальних норм фактичних даних/об'єктів, які згодом можуть набути статусу доказів. Збирання здійснюється сторонами КП та потерпілим у порядку, передбаченому КПК (ч. 1 ст. 93 КПК). Автори підручника з кримінального процесу (В. Тацій, Ю. Грошевий, О. Капліна, О. Шило) вважають, що збирання доказів - основна можливість та засіб всебіч- ного, повного та неупередженого дослідження всіх обставин КП [19, с. 365].

Деякі автори «перевірку» ототожнюють 3 «дослідженням». О. Капліна вважає, що метою перевірки доказів $\epsilon$ «визначення їх придатності для становлення обставин, що мають значення для справи» [20, с. 223]. В. Гончаренко, В. Нор, М. Шумило як автори науково-практичного коментаря до КПК визначають перевірку як «поєднання розумового (логічного) процесу з практичними діями СД з дослідження одного чи кількох доказів, переважно з метою встановлення їхнього змісту та допустимості» $[21$, с. 255].

У науковій літературі оцінку розглядають як розумову діяльність уповноваженого суб'єкта, що полягає в дослідженні якісних і кількісних ознак зібраних доказів і здійснюється за його внутрішнім переконанням. Проте слід зауважити, що лише оцінка доказів судом носить владний характер, оскільки судові рішення, в яких відбивається ця оцінка, $є$ обов'язковими. Формалізоване визначення оцінки та її суб'єктів (слідчий, прокурор, слідчий суддя, суд) наведено в ст. 94 КПК. Тут слід відзначити, що в нормах ст. 9 та ст. 94 КПК наявна невідповідність щодо складу суб'єктів, які здійснюють оцінку, зі ст. 94 КПК виключений керівник органу досудового розслідування, а додані слідчий суддя та суд.

Надалі, враховуючи мету дослідження, пропонуємо розглядати лише деякі актуальні питання щодо СД у КП про ППІВ.

Сторона обвинувачення. У п. 19 ст. 3 КПК до сторони обвинувачення ${ }^{2}$ віднесені: слідчий, керівник органу досудового розслідування, прокурор, потерпілий. Незважаючи на відсутність згадки в п. 19 ст. 3 КПК, до § 2 чинного КПК введено нового учасника сторони обвинувачення - оперативні підрозділи. Під час виконання доручень слідчого, прокурора співробітник оперативного підрозділу користується повноваженнями слідчого (ч. 2 ст. 41 КПК).

Відповідно до ч. 2 ст. 9 КПК прокурор, керівник органу досудового розслідування, слідчий зобов'язані всебічно,

\footnotetext{
${ }^{2}$ Оскільки порушення ПІВ, відповідно до класифікації правопорушень, віднесені виключно до кримінальних правопорушень, дізнавач та керівник органу дізнання як суб'єкти доказування не розглядаються.
} 
повно і неупереджено дослідити обставини КП, виявити як ті обставини, що викривають, так і ті, що виправдовують підозрюваного, обвинуваченого, а також обставини, що пом'якшують чи обтяжують його покарання, надати їм належну правову оцінку та забезпечити прийняття законних і неупереджених процесуальних рішень. Стаття 92 КПК конкретизує обов'язок доказування за обставинами та суб'єктами:

- предмету доказування (ст. 91 КПК) - покладається на слідчого, прокурора та в установлених КПК випадках - на потерпілого;

- належності й допустимості доказів, даних щодо розміру процесуальних витрат та обставин, які характеризують обвинуваченого - покладається на сторону, що їх подає.

Оскільки метою кримінального процесуального пізнання $\epsilon$ одержання знання про факти/обставини, що становлять предмет доказування, і на слідчого покладено обов'язок доказування, слідчий $є$ основним СД, який під час пізнавально-посвідчувальної діяльності здійснює збір, перевірку та оцінку відомостей.

Мета й обов'язки слідчого визначені, однак для з'ясування, за якими основними напрямами слідчий їх реалізовує, стисло зупинимося на підходах до поняття «кримінально-процесуальна функція». у ч. 3 ст. 22 КПК законодавець визначив 3 функції: державне обвинувачення, захист, судовий розгляд. Серед науковців відсутня єдність думок щодо згаданих функцій. М. Шумило зазначає, що в новому КПК залишився «інституційний релікт радянського періоду - злиття функцій розслідування і обвинувачення» [22].

У літературі вказується на суперечність між положеннями ч. 3 ст. 22 КПК та пунктами 17 та 19 ст. 3 КПК, за якими на слідчого покладено 2 функції: здійснення досудового розслідування (п. 17) та обвинувачення (п. 19). Однак вагому підтримку має думка, що слідчий виконує винятково функцію розслідування кримінального правопорушення. За результатами опитування працівників правоохоронних органів і суддів, 69,5\% респондентів відповіли, що слідчий здійснює функцію розслідування [23, с. 103, 561]. Ще одним аргу- ментом, що підтверджує саме цю функцію слідчого, $\epsilon$ момент висунення обвинувачення прокурором. Виходячи із сукупності дій в доказуванні, слідчий фактично здійснює підготовку до формування доказової бази, а прокурор після ії̈ перевірки та оцінки здійснює її формування й одну зі своїх основних функцій - висунення обвинувачення. На підставі зазначеного важко погодитись із тим, що слідчий здійснює функцію обвинувачення.

В. Гончаренко вважає, що «слідчий повинен бути виведений за межі сторін, що змагаються, оскільки він за законом ретельно і неупереджено має збирати як обвинувальні, так і виправдувальні докази» [24, с. 77]. Начальник ГСУ Нацполіції України М. Цуцкірідзе висловився про дуалістичну природу пізнання слідчим: «Слідчий «йде за слідом» імовірного злочинця. Але не лише з метою пізнати, хто саме вчинив протиправне діяння, a й для того щоб поставити через прокурора питання перед судом про кримінальне покарання особи» [25, с. 92].

Перевірка та оцінка отриманих слідчим даних надає можливість рухатися далі та обґрунтовувати відповідні процесуальні рішення, в т.ч. для отримання нових доказів. Наприклад, наявність в оголошенні про продаж продукції з ознаками фальсифікації інформації про доставку через кур'єрські служби доставки «А», «Б» зумовлює звернення слідчого до суду для отримання ухвали про тимчасовий доступ до документів «А», «Б» з метою отримання відомостей про здійснені продавцем відправлення.

Практика в провадженнях про ППІВ свідчить, що керівник органу досудового розслідування майже не втручається в розслідування, крім вирішення одиничних організаційних питань. Водночас, ураховуючи специфіку злочинів даної категорії, вважаємо за доцільне рекомендувати даному суб'єкту оптимізувати хід розслідування шляхом визначення слідчого (слідчих), які вже мають досвід розслідування аналогічних злочинів.

Важливу роль у зборі, перевірці та оцінці фактичних обставин відіграє співробітник оперативного підрозділу, оскільки за дорученням слідчого він реалізує специфічні повноваження - НСРД, які 
$\epsilon$ важливим і дієвим засобом доказування ППIВ. Протокольна форма підготовки матеріалів (результатів НСРД) дещо уповільнює досудове розслідування, однак за належної організації виконання доручення слідчого/прокурора здійснюється паралельно з іншими процесуальними діями.

Державне обвинувачення - процесуальна діяльність прокурора, що полягає в доведенні перед судом обвинувачення з метою забезпечення кримінальної відповідальності особи, яка вчинила кримінальне правопорушення (п. 3 ст. 3 КПК). Прокурор - центральний суб'єкт сторони обвинувачення, зобов'язаний, зокрема: розпочати КП у випадку безпосереднього виявлення ознак ППІВ або надходження заяви про кримінальне правопорушення, здійснювати процесуальне керівництво досудовим розслідуванням, погоджувати обвинувачення, тобто повністю відповідати за його результати та підтримувати обвинувачення в суді.

Всі учасники сторони обвинувачення реалізують усі елементи доказування на виконання обов'язку - прийняття законних і неупереджених процесуальних рішень, однак кожен із власною метою, яка визначається їхньою процесуальною функцією.

Звертаємо увагу, що в КП про ППІВ серед слідчих тривалий час відсутня єдність у питанні початку досудового розслідування. За аналогічними фактами (в заявах), одні слідчі вносять відомості до ЄРДР, а інші - ні. Така ситуація призводить до втрати часу на оскарження потерпілим бездіяльності слідчого, тоді як порушення продовжується. Потерпілі змушені користуватися іншим процесуальним механізмом - звертатися із заявою до прокурора. За результатами аналізу ЄДРСР відзначено збільшення кількості КП, розпочатих прокурором.

Потерпілий - фізична особа, якій кримінальним правопорушенням завдано моральної, фізичної або майнової шкоди, юридична особа, якій кримінальним правопорушенням завдано майнової шкоди... (ч. 1 ст. 55 КПК). Права потерпілому необхідні для відновлення порушених прав і відстоювання власних інтересів. Дискусія починається вже з визначення статусу потерпілого. 3 одного боку, він віднесе- ний до сторони обвинувачення (п. 19), а в п. 25, 26 ст. 3 КПК - відокремлений від сторін КП.

Чинний КПК розширив права потерпілого, починаючи з моменту їх виникнення (подання заяви про вчинення щодо неї кримінального правопорушення або заяви про залучення до провадження як потерпілого - ст. 55 КПК), і не передбачає винесення постанови про визнання потерпілим. Не згодні з новелою вважають, що подання заяви не свідчить про внесення відомостей до ЄРДР, початок розслідування та можливість реалізації прав стороною обвинувачення і потерпілим. Гострота дискусії та правозастосування вивели проблему на рівень Великої Палати Верховного Суду. У постанові ВП ВС [26] форма та момент початку досудового розслідування деталізовані: «...навіть у разі, якщо потерпілий не подавав до правоохоронних органів заяви про злочин як окремого процесуального документа, однак до початку чи під час досудового розслідування i/або судового провадження однозначно висловив Свою позицію про притягнення винного до кримінальної відповідальності, відповідна позиція, зафіксована у процесуальних документах, дає підставу для кримінального переслідування особи за злочин приватного обвинувачення». Практики назвали такий спосіб початку досудового розслідування «альтернативним».

Про необхідність упорядкування прав потерпілого свідчать фрагментарно розкидані по КПК права, іноді суперечливі. Згідно з п. 3 ч. 1 ст. 56 КПК протягом КП потерпілий має право подавати докази слідчому, прокурору, слідчому судді, суду. Водночас із п. 3 ч. 2 ст. 56 КПК вбачається, що під час досудового розслідування потерпілий має право подавати докази (лише - Є.К.) на підтвердження своєї заяви, що звужує попередню норму. Про право потерпілого на подання доказів у судовому провадженні (4. 3 ст. 56 КПК) не вказується, що дисонує з п. 3 ч. 1 цієї статті та засадою змагальності. Отже, вважаємо, що зміст закону вказує на суперечність норм як у межах ст. 56 КПК, так і загалом у КПК.

Право потерпілого на збирання, перевірку та оцінку доказів у ст. 56 КПК не закріплене, однак це не свідчить про 
його відсутність. Відповідно до ст. 93 КПК потерпілий збирає докази шляхом витребування та отримання від органів державної влади, органів місцевого самоврядування, підприємств, установ, організацій, службових та фізичних осіб речей, копій документів, відомостей, висновків експертів, висновків ревізій, актів перевірок; ініціювання проведення СРД, НСРД та інших процесуальних дій, а також шляхом здійснення інших дій, які здатні забезпечити подання суду належних і допустимих доказів. Займенник «інших» указує на невичерпність способів збирання доказів, що $€$ позитивом. Ініціювання потерпілим проведення СРД здійснюється шляхом подання клопотань слідчому, прокурору.

Потерпілий нормативно не віднесений до суб'єктів перевірки й оцінки доказів (ст. 94 КПК), однак надані йому права: безпосередності дослідження доказів у суді (п. 3 ч. 3 ст. 56 КПК), підтримання обвинувачення в разі відмови прокурора (4. 3 ст. 340 КПК), ініціювання встановлення обставин або перевірки обставин, які мають істотне значення в ході судового розгляду (ч. 3 ст. 333 КПК), висловлення думки про призначення покарання (п. 5 ч. 3 ст. 56 КПК), виступу в дебатах, які свідчать про проходження потерпілим/ представником логічного ланцюжка: поняття-судження-умовивід, тобто здійснення перевірки й оцінки зібраних доказів, як кожного окремо, так і їх сукупності.

Водночас ми не погоджуємося з авторами, які покладають на потерпілого обов'язок доказування:

- обставин предмету доказування (ст. 91 КПК) у випадку відмови прокурора від підтримання державного обвинувачення (ст. 340 КПК);

- належності й допустимості доказів, даних щодо розміру процесуальних витрат та обставин, які характеризують обвинуваченого, в разі подання таких доказів.

На підставі аналізу ст. 340 КПК вважаємо, що підтримання обвинувачення потерпілим - це не обов'язок, а право, яке може бути реалізоване лише за згоди останнього (ч. 3, 4 ст. 340). Обов'язок доводити належність і допустимість доказів, указаних у ч. 2 ст. 92 КПК, є факультативним і виникає лише після їх подання.
Злочини проти IB становлять порушення конституційного права особи на використання та поширення результатів IB. Право IB суб'єктне, а тому в КП завжди $€$ потерпілий - власник ПІВ або ліцензіат. Оскільки ПІВ можуть охороняти як приватні, так і публічні права, законодавець розділив відповідні правопорушення на правопорушення приватного обвинувачення (ч. 1 ст. 176, 177 ККУ, ст. 229 ККУ) і публічного (ч. 2, 3 ст. 176, 177 ККУ). Керуючись вищенаведеною позицією ВП ВС, вважаємо, що засада диспозитивності для сторони обвинувачення $\mathrm{HE}$ ОБМЕЖУЄТЬСЯ законодавчим приписом про те, що КП у формі приватного обвинувачення розпочинається лише на підставі заяви потерпілого (ч. 4 ст. 26 КПК). Для потерпілого ж ця засада підкреслює можливість активності в захисті власних прав, зокрема через активну участь у доказуванні. Як слушно зазначав О. Рибалка, «потерпілий як суб'єкт доказування характеризується подвійною природою наданого обсягу прав і обов'язків, оскільки він $\epsilon$ не тільки суб'єктом процесу зі сторони обвинувачення, а й джерелом самостійного виду доказів - показань потерпілого» [27]. Тут варто додати і про можливість активної участі потерпілого або його представника і в низці слідчо-судових дій.

у провадженнях про ППІВ окремої уваги потребує процесуальна дія - добровільна видача потерпілим/представником документів, речей тощо. Виходячи з практики, саме вони, належним чином процесуально оформлені слідчим, як окремо, так і в сукупності з іншими доказами сторони обвинувачення, переконливо спростовують різні доводи сторони захисту. У постанові [28] Верховний Суд вказав на допустимість добровільно виданих доказів, зафіксованих у відповідному протоколі.

Відзначимо, що потерпілим у КП про ППІВ $€$ особа, які захищає власні порушені права, а в доказуванні майже завжди має інтерес - відшкодування збитків. При цьому деякі потерпілі, що вперше стикнулися зі злочинним ППІВ в Україні, висловлюють хибну думку про недоцільність їхньої активної участі в провадженні, оскільки обов'язку доказування вони не несуть. Першого разу вони лише 
подають заяву до поліції та ідентифікують вилучену продукцію як фальсифіковану. Надалі лише високий ступінь активності в доказуванні дає позитивні результати. В іншому випадку потерпілим залишається спостерігати за процесом осторонь і відмічати збільшення кількості фальсифікованої продукції на ринку.

Сторона захисту - підозрюваний, обвинувачений (ст. 42 КПК), виправданий, засуджений (ст. 43 КПК), законний представник підозрюваного, обвинуваченого (ст. 44 КПК), захисник (ст. 45 КПК). Захисник бере участь у КП не тільки для захисту від обвинувачення, а й для виконання однієї з функцій держави - захисту законних прав і свобод громадян.

На відміну від прав потерпілого серед прав підозрюваного, обвинуваченого вказані: збирати і подавати слідчому, прокурору, слідчому судді, суду докази (ч. 1 ст. 20, ч. 3, 4 ст. 42 КПК). Згідно з КПК захисник користується правами підозрюваного та обвинуваченого, крім процесуальних прав, реалізація яких здійснюється безпосередньо підозрюваним, обвинуваченим і не може бути доручена захиснику. Сторона захисту, як і потерпілий, збирає докази через ініціювання клопотань перед слідчим. Сторона захисту також нормативно не віднесена до суб'єктів перевірки й оцінки доказів (ст. 94 КПК), однак надані їй права: залучати експерта (ст. 243 КПК), оскаржувати повідомлення про підозру (п. 10 ч. 1 ст. 303 КПК), заявляти клопотання про повернення обвинувального акту (п. 3 ч. 3 ст. 314 КПК), участь під час судового розгляду в допиті свідків (п. 1 ч. 4 ст. 42 КПК), висловлювати в судовому засіданні свою думку щодо клопотань інших учасників (п. 3 ч. 4 ст. 42 КПК), ініціювати встановлення або перевірку обставин у ході судового розгляду (ч. 3 ст.333 КПК), виступ у дебатах, свідчать про можливість перевірки й оцінки зібраних доказів.

I. Одинцова пропонує доповнити КПК статтею «93-1 Діяльність захисника щодо здійснення збирання, дослідження та перевірки доказів (паралельне розслідування)» в якій передбачити засоби, форми, методи отримання та фіксації доказів» [5, с. 3]. Така пропозиція видається намаганням копіювати змагальний про- цес Англії, де адвокат і прокурор мають рівні права. Але, як влучно підкреслив В. Тертишник, «спроби винайти будь-яку спеціальну форму діяльності захисника зі збирання та дослідження доказів можуть призвести тільки до невиправданої ерозії існуючої та апробованої процесуальної форми» [29, с. 248].

Виходячи із презумпції невинуватості, сторона захисту не зобов'язана збирати і подавати докази. Однак за наявності їх подання слідчому, прокурору або суду можливо розглядати як процесуальний обов'язок захисту на спростування фактів/обстави, тобто дії, щоб завадити притягненню клієнта до кримінальної відповідальності, обов'язок доказування сторони захисту лише в частині належності та допустимості поданих ними доказів (ч. 2 ст. 92 КПК). Тривала дискусія і перманентний процес урівнювання прав сторін ще не досягли мети, задекларованої в ст. 22 КПК. Як і раніше, залишається «слабка сторона» і потерпілий, який іноді має ще менше прав. Як приклад нерівності прав захисту і потерпілого наведемо ситуацію із залученням експерта за ст. 243 КПК, за якою захист має право як на самостійне залучення експерта, так і через суд, а потерпілому таких прав не надано. Як ми бачимо, законодавство закріплює низку прав, які надають захиснику можливість брати активну участь у доказуванні. Однак виходячи з аналізу правозастосування, можемо стверджувати, що активність або пасивність захисника - це питання тактики (вибраної лінії захисту) і професійної підготовки.

Участь захисника у КП про ППІВ має свою специфіку. Більшість злочинів проти ПІВ віднесені до злочинів невеликої тяжкості, а тому відсутні законодавчі підстави для обов'язкової участі захисника. При цьому специфічні правопорушення, сфера регулювання та участь захисників у переважній більшості ${ }^{3}$ проваджень (іноді 2-3 одразу) свідчать, що дана категорія справ $\epsilon$ складною. Також специфіка полягає в тому, що складно спростувати очевидні порушення норм матеріального права

\footnotetext{
${ }^{3}$ Автором проаналізовано 439 обвинувальних вироків з Єдиного державного реєстру судових рішень за ст. 176, 229 КК України за період з 01.01.2010 р. по 01.01.2021 p.
} 
(фактів використання ОПIВ, зокрема виробництво, продаж, камкординг тощо), а тому захист $\epsilon$ пасивним у збиранні доказів спростування таких фактів. Тому мета захисника - пошук процесуальних помилок сторони обвинувачення.

Цивільний позивач. Згідно з ч. 3 ст. 61 КПК цивільний позивач (далі - ЦП) має права та обов'язки, передбачені цим Кодексом для потерпілого в частині, що стосуються цивільного позову. Незважаючи на інтерес у доказуванні майнової та/або моральної шкоди, завданої внаслідок правопорушення, слід відзначити, що в п. 19 ст. 3 КПК законодавець не відніс ЦП до сторін КП. У цьому вбачається суперечність із п. 26 ст. 3 КПК (сторони судового провадження), оскільки під час досудового розслідування і судового розгляду особа, що зазнала майнової та/або моральної шкоди, наділяється правами потерпілого, який віднесений до сторони обвинувачення.

В юридичній літературі висловлюється думка, що ЦП має факультативний характер участі в КП. Результати аналізу ${ }^{3}$ дають підстави не погодитися з факультативним характером участі ЦП у провадженнях даної категорії, оскільки цивільний позов заявлявся у 238-ми з 439-ти проваджень (54\%). Це також підтверджує активність ЦП у захисті порушеного права. Разом із тим реалізація даного процесуального механізму залежить від: 1) встановлення особи і пред'явлення їй підозри; 2) рішення потерпілого про подання позову до органу досудового розслідування або суду; 3) набуття статусу ЦП.

Системний аналіз норм КПК у взаємозв'язку зі ст. 61 КПК свідчить, що з моменту заявлення цивільного позову права потерпілого звужуються. Фактично потерпілий втрачає не лише можливість збору, перевірки, подання доказів щодо інших обставин КП, які не стосуються позову, а й низку прав, для прикладу, оскаржувати рішення, дії чи бездіяльність (ст. 303 КПК), ознайомлюватися з матеріалами, які безпосередньо стосуються вчиненого щодо нього кримінального правопорушення (п. 11 ч. 1 ст. 56 КПК), брати участь у СРД (п. 4 ч. 2 ст. 56 КПК). 3 одного боку, активний потерпілий після пред'явлення підозри намагається якнайшвидше подати позов і клопотання про накладення арешту на майно підозрюваного для забезпечення відшкодування шкоди. А з іншого - як ЦП законодавець забирає у потерпілого низку процесуальних прав, у т.ч. подальшу активну участь у судовому доказуванні.

Експерт, спеціаліст. Незрозумілою $\epsilon$ логіка законодавця, який включає експерта до учасників кримінального провадження (п. 25 ст. 3 КПК), надає низку прав у різних за ієрархією законодавчих актах (КПК, ЗУ «Про судову експертизу», Інструкції про призначення та проведення експертиз), однак не включає його до учасників судового провадження. Можливо, причина в тому, що експерт не обов'язково залучається до судового розгляду, оскільки його висновок уже сам по собі $\epsilon$ джерелом доказів! Переважна більшість дослідників називають експерта «технічним спеціалістом», «допоміжним суб'єктом» та не вважають його СД. Заборона самостійно збирати матеріали для дослідження, встановлена в ст. 69 КПК, здавалось би, зводить нанівець подальші дискусії щодо експерта як СД.

Однак ми підтримуємо А. Белкина, який відносить експерта до СД [30, с. 27]. У запропоноване Р. Савонік поняття СД «особи, які притягуються або залучаються до участі в доказуванні за рішенням органів і службових осіб, котрі здійснюють процесуальну діяльність у зв'язку з розслідуванням справи» [1, с. 8] - цілком вписуються експерт і спеціаліст.

У провадженнях про ППІВ роль осіб, які мають спеціальні знання, часто $€$ вирішальною: встановлення фальсифікації продукції, використання ОПІВ, визначення розміру збитків. На прикладі проваджень про ППІВ ми заперечмо позицію науковців і покажемо, що діяльність експерта фактично включає всі елементи доказування:

1. Збирання матеріалів опосередковано (через клопотання до слідчого) або безпосередньо у ході огляду місця події. Для прикладу, відбирає-вилучає зразки швів з обладнання, на якому здійснювалося пошиття фальсифікованої продукції. Мета таких дій - отримання нового знання під час виконання експертного завдання. Існує думка, що такі дії $\epsilon$ дублюванням повноважень слідчого. Не погодимося, оскільки без спеціальних знань і вмінь 
такі дії слідчим не можуть бути проведені. Тому експерт здійснює збирання матеріалів/об'єктів, які згодом можуть стати доказами;

2. Перевірка наданих матеріалів/ об'єктів як пізнавально-практична діяльність;

3. Оцінка отриманих результатів і даних, що були надані експерту для вирішення експертного завдання. В обґрунтування статусу експерта як СД, який здійснює оцінку (логічне осмислення) результатів перевірки, також підкреслимо право експерта вказувати у висновку на виявлені в ході проведення експертизи факти, які мають значення для справи і щодо яких йому не були поставлені питання (п. 2 ст. 13 ЗУ «Про судову експертизу»). Вважаємо, що аналогічні доводи можуть стосуватися і спеціаліста як СД.

Слідчого суддю та суд ми не вважаємо суб'єктами доказування, однак про це піде розмова в наступних публікаціях.

Висновки. Збирання, подання та оцінка доказів як обов'язок або право - це дієва можливість реалізації статусу суб'єктів доказування, які мають власні або представляють інтереси інших осіб. Неузгодженість положень ст. 9, 94 КПК та 3, 22 КПК ускладнює розуміння поняття суб'єктів доказування. Відсутність єдності в правозастосуванні ст. 214 КПК свідчить про необхідність випрацювання єдиного підходу, який би сприяв прискоренню здійснення досудового розслідування. Впорядкування прав потерпілого, узагальнення правозастосування та активна участь потерпілого в доказуванні сприятимуть більш дієвому захисту прав інтелектуальної власності. Активна участь захисника в доказуванні сприятиме ефективному здійсненню функції захисту. Для зміни долі цивільного позивача як спостерігача, обгорнутого пред'явленим позовом у значні процесуальні обмеження, пропонуємо розширити права цивільного позивача. Наведені аргументи щодо експерта і спеціаліста як суб'єктів доказування можуть зрушити з місця усталене сприйняття цих суб'єктів як допоміжних учасників.

\section{ЛITEPATУРА:}

1. Савонюк Р.Ю. Слідчий як суб'єкт кримінально-процесуального доказування : дис ... канд. юрид. наук. Київ : НАВСУ, 2002. 230 с.

2. Юрчиниш В.М. Функції прокурора у досудовому розслідуванні: теорія і практика : дис. ... док. юрид. наук. Запоріжжя, 2016. 443 с.

3. Давиденко С.В. Потерпілий як суб'єкт кримінально-процесуального доказування : автореф. дис. ... канд. юрид. наук. Харків, 2007. 20 с.

4. Обрізан Н.М. Захисник як суб'єкт доказування в кримінальному процесі : автореф. дис. ... канд. юрид. наук. Київ : КНУВС, 2008. 16 с.

5. Одинцова I.М. Ефективність інституту захисту в кримінальному процесі (вітчизняний досвід реформ та європейські стандарти) : дис. ... канд. юрид. наук. Дніпро, 2017. 227 с.

6. Михайлів С.В. Адвокат-представник потерпілого у кримінальному процесі : автореф. дис. ... канд. юрид. наук. Київ, 2011. 18 с.

7. Великий тлумачний словник сучасної української мови / уклад. і голов. ред. В.Т. Бусел. Київ : Ірпінь: ВТФ «Перун», 2003. 1440 с.

8. Коваленко Є.Г. Теорія доказів. Київ : Юрінком Інтер, 2006. 321 с.

9. Барабаш Т.М. Нормативно-правові підходи до визначення суб'єкта доказування в кримінальному процесі України. Наукові записки Інституту законодавства Верховної Ради України. 2011. № 3 (6). С. 109-114.

10. Нор В.Т. Проблеми теорії і практики судових доказів. Львів : Вища шк., 1978. С. 52.

11. Ляш А.О., Стахівський С.М. Докази і доказування в кримінальному судочинстві : навч. посіб. Київ : Ун-т «Україна», 2005. С. 139.

12. Тертышник В.М., Слинько С.В. Теория доказательств. Харьков : Арсис, 1998. 256 с.

13. Доказування у кримінальному провадженні: курс лекцій / О.О. Бондаренко та ін. ; за заг. ред. д-ра юрид. наук, проф. О.О Юхна ; МВС України. Харків : ХНУВС, 2018. 156 с.

14. Стахівський С.М. Кримінально-процесуальні засоби доказування : автореф. дис. ... докт. юрид. наук. Київ : КНУВС, 2005. 30 с.

15. Кримінальний процес : підручник / за заг. ред. В.В. Коваленка, Л.Д. Удалової, Д.П. Письменного. Київ : Центр учбової літератури, 2013. 544 с. 
16. Вапнярчук В.В. Суб'єкти кримінального процесуального доказування. Вісник Національної академії правових наук України. Харків, 2014. № 1. С. 160-168.

17. Погорецький М.А. Нова концепція кримінального процесуального доказування. Вісник кримінального судочинства. 2015. № 3. С. 63-79.

18. Грошевий Ю.М, Стахівський С.М. Докази і доказування у кримінальному процесі : наук.-практ. посіб. Київ : КНТ ; Вид. Фурса С.Я., 2006. С. 45.

19. Кримінальний процес : підручник / Ю.М. Грошевий та ін.; за редакцією В.Я Тація та ін. Харків : Право, 2013. 824 с.

20. Капліна О.В. Збирання доказів сторонами кримінального провадження за КПК України. Актуальні проблеми доказування у кримінальному провадженні : матеріали Всеукраїнської інтернет-конференції (м. Одеса, 27 листопада 2013 р.). Одеса, 2013. С. 223-229.

21. Кримінальний процесуальний кодекс України. Науково-практичний коментар / за загальною редакцією професорів В.Г. Гончаренка, В.Т. Нора, М.Є. Шумила. Київ : Юстініан, 2012. 1224 c.

22. Шумило М.Є. Роль науки в критичній рефлексії положень КПК України. URL: http://elar.naiau.kiev.ua/ (дата звернення: 01.08.2021).

23. Гловюк I. Кримінально-процесуальні функції: теоретико-методологічні засади і практика реалізації : дис. ... док. юрид. наук. Одеса : Нац.ун-т «Одеська юрид. академія», 2015. 579 c.

24. Гончаренко В.Г. Правове становище потерпілого у кримінальному судочинстві України. Вісник Академії адвокатури України. 2016. Т. 13. № 2. С. 75-79.

25. Цуцкірідзе М.С. Досудове розслідування: процесуальна функція слідчого чи різновид пізнавальної діяльності. Науковий вісник Міжнародного гуманітарного університету. Сер.: Юриспруденція. 2017. № 30. Т. 2. С. 90-93.

26. Постанова ВП ВС від 03.07.2019 р. у справі № 288/1158/16-к. URL: https:// reyestr.court.gov.ua/Review/82998245 (дата звернення: 01.08.2021).

27. Рибалка О.В. Суб'єкти кримінально-процесуального доказування : дис. ... канд. юрид. наук. Київ : НАВСУ, 2010. 217 с.

28. Постанова ВС ККС від 21.01.2019 р. у справі № 130/1381/16-к. URL: https:// reyestr.court.gov.ua/Review/80112211 (дата звернення: 01.08.2021).

29. Тертишник В.М. Кримінально-процесуальне право України. Київ : Юрінком Інтер, 1999. 536 c.

30. Белкин А.Р. Теория доказывания. Научно-методическое пособие. Москва : Норма, 1999. 429 с. 